\title{
Management of Chiari I deformity in Children and Adolescents: A report from the Consensus Taskforce of the Brazilian Society of Pediatric Neurosurgery
}

\section{Avaliação e manejo da deformidade de Chiari I em crianças e adolescentes: Recomendações e resultados da Reunião de Consenso sobre Controvérsias da Sociedade Brasileira de Neurocirurgia Pediátrica}

\author{
Marcelo Volpon Santos 1 \\ Antonio Rosa Bellas ${ }^{4}$ Marcia Cristina da Silva ${ }^{50}$ \\ ${ }^{1}$ Division of Pediatric Neurosurgery, Department of Surgery and \\ Anatomy, University of São Paulo, Ribeirão Preto Medical School, \\ Ribeirão Preto, SP, Brazil \\ ${ }^{2}$ Department of Neurosurgery, King's College Hospital NHS \\ Foundation Trust, London, United Kingdom \\ ${ }^{3}$ Division of Pediatric Neurosurgery, Universidade Estadual de \\ Londrina, Londrina PR, Brazil \\ ${ }^{4}$ Division of Pediatric Neurosurgery, Fernandes Figueira Hospital - \\ Fundação Oswaldo Cruz, Rio de Janeiro, RJ, Brazil \\ ${ }^{5}$ Department of Neurosurgery, João XXIII Hospital, Belo Horizonte, \\ MG, Brazil \\ ${ }^{6}$ Department of Neurosurgery, Federal University of São Paulo, \\ São Paulo, SP, Brazil \\ 7 Division of Neurosurgery, Department of Surgery and Anatomy, \\ Ribeirão Preto Medical School, University of São Paulo, Ribeirão \\ Preto, SP, Brazil
}

Alexandre Casagrande Canheu ${ }^{3}$

Sergio Cavalheiro ${ }^{6 \odot}$ Ricardo Santos de Oliveira ${ }^{7 \odot}$

Arq Bras Neurocir 2020;39(2):125-131.

Address for correspondence Marcelo Volpon Santos, MD, PhD, Divisão de neurocirurgia pediátrica, Departamento de cirurgia e anatomia, Faculdade de Medicina de Ribeirão Preto - Universidade de São Paulo, Av. Bandeirantes, 3900, Vila Monte Alegre - Campus Universitario, Ribeirão Preto, SP CEP 14049-900, Brazil (e-mail: marcelovolpon@usp.br).
Abstract
Keywords
- chiari I deformity
- craniocervical junction
- filum terminale
- guidelines
- hindbrain hernia
- tonsillar ectopia

Much controversy remains on the current management of Chiari I deformity (CID) in children, with many clinical, surgical and ethic-legal implications. The Brazilian Society of Pediatric Neurosurgery (SBNPed, in the Portuguese acronym) has put together a panel of experts to analyze updated published data on the medical literature about this matter and come up with several recommendations for pediatric neurosurgeons and allied health professionals when dealing with CID. Their conclusions are reported herein, along with the respective scientific background. received

December 19, 2019

accepted

January 15,2020
DOI https://doi.org/

10.1055/s-0040-1708890. ISSN 0103-5355.
Copyright $(2020$ by Thieme Revinter

Publicações Ltda, Rio de Janeiro, Brazil
License terms

(c) $(1) \$$ 


\section{Resumo}

Palavras-chave

- deformidade de Chiari I

- diretrizes

- ectopia

- herniação tonsilar

- phyllo terminal

- junção craniocervical
Atualmente, ainda persiste muita controvérsia sobre o manejo da deformidade de Chiari I (CID) em crianças, com diversas implicações clínicas, cirúrgicas e ético-legais. Desta forma, a Sociedade Brasileira de Neurocirurgia Pediátrica (SBNPed) reuniu um painel de especialistas para analisar dados atualizados publicados na literatura médica sobre essa entidade clínica e formulou uma série de recomendações, a fim de padronizar as condutas e auxiliar a tomada de decisões clínicas de neurocirurgiões pediátricos e demais profissionais de saúde que tratam de crianças com CID. Suas conclusões são relatadas aqui, juntamente com o respectivo respaldo científico.

\section{Introduction}

Chiari type I deformity (CID) is relatively common in children, and the ever-increasing availability of high-definition diagnostic imaging has resulted in a growing number of referrals for this condition to pediatric neurosurgeons. ${ }^{1}$ Much controversy still remains on the management of Chiari type I deformity in children, especially in asymptomatic or oligosymptomatic patients. To overcome this, the Brazilian Society of Pediatric Neurosurgery (SBNPed, in the Portuguese acronym) has organized, in August 2019, a consensus meeting for the discussion of CID, held in the city of Londrina, state of Paraná, Brazil, to analyze the most updated medical literature regarding this topic, gather the opinions of national and international experts and standardize evaluation and management strategies. This consensus report is addressed to pediatric and general neurosurgeons, pediatricians, allied professionals, health managers and decision makers who might get involved in the treatment of this condition.

\section{Methods}

A panel composed of members of the Board of Directors and Scientific Committee of the SBNPed put together the scientific program of the consensus meeting, which comprised the main clinical and surgical issues concerning the management of CID patients. Brazilian and foreign specialists were invited to present data available in the literature and to provide a critical summary and analysis of such information. All of the authors were asked to strictly follow guidelines of the Oxford Centre for Evidence-based Medicine, grading published studies in accordance with their levels of evidence and grades of recommendation. ${ }^{2,3}$

All of the statements described herein have taken into consideration this hierarchy, and priority has been given to the highest levels of data quality available. Data was obtained through standard clinical searches in the Medline, Cochrane, Scielo and LILACS databases, with correspondent MeSH terms. By the end of the meeting, an algorithm for the management of CID was formulated (in strict accordance with the scientific data discussed) and approved by all members of the consensus taskforce ( $\mathbf{- F i g . 1}$ ). Also, a letter to the editor of an international pediatric neurosurgery publication has been sent, ${ }^{4}$ on the grounds that such journal had recently published a full edition solely about $\mathrm{CID},{ }^{5}$ and that this consensus report would further expand the discussion in the subject and underline the standards recommended by the SBNPed.

\section{Clinical Questions}

1) What is the definition and best nomenclature of CID?

Ever since the first descriptions of this clinical entity by Hans Chiari himself in $1891^{6}$, it has been referred to as "malformation." Nevertheless, this term does not seem to be directly applicable, for there are many cases without a proper malformation, with normal neurovascular structures of the posterior fossa, ${ }^{6}$ and a reappraisal of this terminology has been published recently, as it relates to an acquired rather than developmental pathology.,7 Therefore, for the pathophysiological aspects discussed below, the consensus taskforce has reached a decision to call it Chiari I deformity (CID), and this denomination will be used henceforth.

Regarding its definition, CID is usually characterized by a descent of the cerebellar tonsils below the level of the foramen magnum; the extent of this descent is what differs in the literature, with authors considering it significant from 3 to $8 \mathrm{~mm} .{ }^{8,9}$ Furthermore, the description of the so-called Chiari 0 and Chiari 1.5 , while referring to recognizable radiological entities, has added further confusion rather than clarifying the situation. ${ }^{5,7}$ Analyzing all these papers, the consensus group has defined CID as "a tonsillar ectopia of 5 (five) millimeters or more below the level of the foramen magnum."

2) What is the physiopathology of CID?

Several authors have addressed this issue. ${ }^{10-15}$ The prevailing idea that CID children have smaller posterior fossa volumes has been reported, ${ }^{15}$ but this finding could not be replicated by many authors, ${ }^{10-12}$ except in children with craniosynostosis, who form a distinct subgroup of patients. ${ }^{13}$ Milhorat et al, ${ }^{14}$ thus, have subdivided the pathophysiological features of CID into five categories: cranial constriction, spinal cord tethering, cranial settling, intracranial hypertension and intraspinal hypotension. There also seems to be an overlapping among these causative factors in any given patient. ${ }^{15}$ 


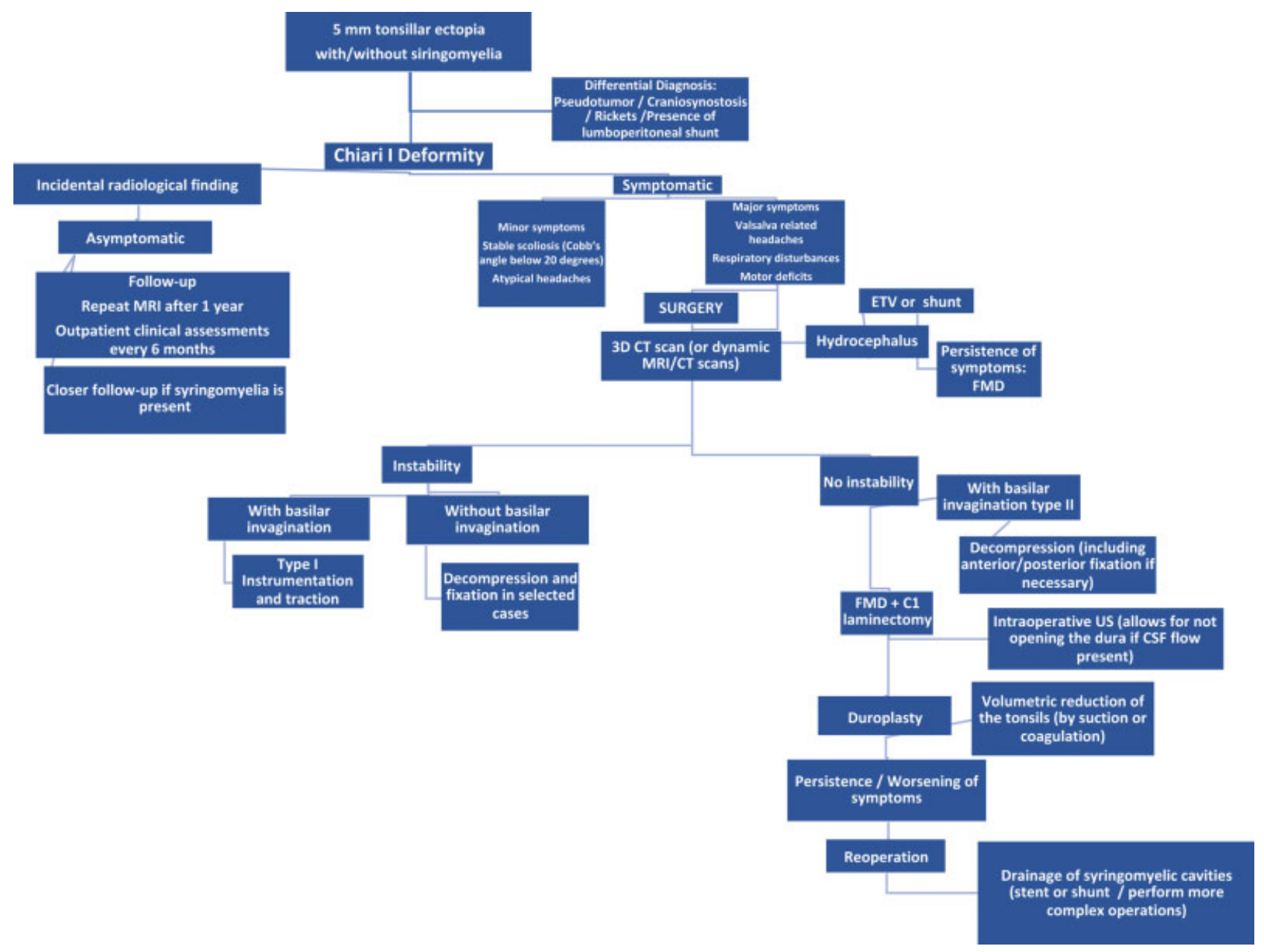

Fig. 1 Algorithm for the Management of Chiari I Deformity in Children according to the recommendations of the Consensus Taskforce of the Brazilian Society of Pediatric Neurosurgery.

Poretti et a $\mathrm{l}^{15}$ have published a comprehensive review of the pathological aspects of CID in children, dividing the possible mechanisms of the development of CID in children into three groups: 1) Primary CID, produced by abnormal growth or mis-segmentation of the craniocervical junction (CVJ); 2) Secondary CID, occurring in patients with abnormal brain expansion (megalencephaly, macrocerebellum) or reduction of the posterior fossa (basilar impression, craniosynostosis); and 3) tonsillar herniation, represented by acquired causes (spontaneous or idiopathic intracranial hypertension, venous congestion due to vascular malformations, expanding intracranial masses).

3) What is the natural history of CID in asymptomatic patients?

In 2008, Novegno et al reported on the natural history of 22 untreated patients with CID: 16 patients (72\%) remained unchanged, and only 3 cases had clinical and or/radiological progression after a mean follow-up of 5.8 years. ${ }^{16}$ Strahle et al, in 2011, studied 142 patients, of whom 133 (90.5\%) did not require treatment (mean follow-up: 3.8 years). ${ }^{17}$ Volpon Santos et al, in 2012, reported on a series of 62 CID children with a longer follow-up (10 years), revealing stability of symptoms with conservative treatment in $72.6 \%$, spontaneous regression in $2.4 \%$, and progression/worsening of symptoms requiring surgery in $27.4 \%{ }^{18}$ Similarly, Pomeraniec et al studied 95 CID pediatric patients and concluded that $92.9 \%$ of the patients managed conservatively did not experience clinical or radiological progression, whereas $41.7 \%$ of those who had presented with symptoms improved during follow-up. ${ }^{19}$ Lastly, Langridge et al have recently performed a systematic review of the natural history and conservative management of adult and pediatric patients with CID. Fifteen papers were included in their meta-analysis, allowing for these authors to conclude that the natural history of mild symptomatic and asymptomatic CID is relatively benign and nonprogressive, and that it is reasonable to observe asymptomatic patients and subjects with mild symptoms even in the presence of significant tonsillar descent or syringomyelia. ${ }^{9}$

The consensus panel acknowledged that asymptomatic patients with incidentally found tonsillar ectopia can be followed-up clinically; a magnetic resonance imaging (MRI) scan should be obtained after 1 year, and clinical assessments should be performed every 6 months. Serial MRI scans are not required as long as the patient remains clinically stable; patients with syringomyelia should be observed more closely.

4) What are the clinical indications for surgery in patients with CID? 
The consensus taskforce has reviewed clinical and radiological indications of surgical treatment for children with CID. For this purpose, clinical manifestations were divided into major and minor, in accordance with several published studies. ${ }^{1,20-24}$ Major clinical symptoms and signs are considered strong indicators for surgery, whereas minor ones should be accompanied by other indicative signs and dealt with on an individual basis.

Major clinical indications include occipital headaches, most often exertional and related to coughing and Valsalva maneuvers, respiratory disturbances (snoring, gagging, sleep apnea), truncal ataxia and corticospinal tract dysfunction (upper and/or lower limb weakness, hyperactive tendon reflexes, Babinski sign, clonus, unilateral and/or bilateral). Minor symptoms and signs listed were atypical headaches (diffuse, migraine-like) and stable scoliosis, especially those with Cobb angle under $20^{\circ}$.

From a radiological standpoint, as indications for surgery, along with the presence of $\mathrm{a} \geq 5 \mathrm{~mm}$ tonsillar ectopia, ${ }^{25,26}$ the following findings could help in the surgical decision ${ }^{21}$ : presence of syrinx, presence of hydrocephalus, and cerebrospinal fluid (CSF) flow disturbance around the foramen magnum (especially on Cine-MRI scans and flow-related sequences).

5) Which operative techniques and adjuncts should be adopted for the surgical management of CID patients?

Traditionally, the standard surgical modality for the treatment of pediatric CID is a posterior fossa craniectomy for foramen magnum decompression (FMD); several studies have confirmed its utility and good results. ${ }^{1,22,25-27}$ It has been used by the majority of pediatric neurosurgeons with only a few distinct technical nuances, which may give rise to some controversy and are discussed herein.

Caldarelli et al have analyzed the required extent of bony resection in 30 pediatric patients and found out that a limited midline suboccipital craniectomy $2.0 \mathrm{~cm}$ long and $2.5 \mathrm{~cm}$ wide with C-1 laminectomy is sufficient for efficient decompression of the FM, yielding good results in 28 (93\%) patients and requiring reoperation in only $2(7 \%) .{ }^{28}$ It is also important to highlight that, in patients with craniosynostosis, the treatment should be aimed at the primary pathology, as stated by many authors. ${ }^{13,29-31}$

The need for dural opening and duraplasty has been initially discussed by Durham et al in 2008, ${ }^{32}$ who concluded that FMD with duraplasty carries a lower risk of reoperation than FMD alone, but a greater risk for CSF-related complications. They also state that the available data on the surgical treatment of CID in children do not allow identification of particular patients who may benefit from the less invasive surgical technique of FMD. In 2011, Hankinson et $\mathrm{al}^{33}$ performed a systematic review of this subject, concluding that, at that time, there was no level I or IIa evidence comparing FMD with and without duraplasty; the notions that FMD with duraplasty has a lower rate of reoperation and that bony decompression alone has a lower rate of CSF-related complications are both based on IIb/B evidence. In 2018, Lin et a ${ }^{34}$ have performed another systematic review and meta-analysis, including 13 articles published until then (and also including adult subjects for a total 3,481 patients in the meta-analysis). Their results showed that duraplasty is an optimal surgical strategy, leading to higher clinical improvement and lower recurrence rate, especially in patients with syringomyelia. However, the authors pointed out that, in patients without syringomyelia, FMD without duraplasty might be the technique of choice, providing similar clinical improvement at lower costs. Lastly, Lu et $\mathrm{al}^{35}$ have performed a meta-analysis of 3,455 pediatric patients, 1,492 (43\%) with and 1,963 (57\%) without duraplasty. The authors concluded that the addition of duraplasty to FM decompression in children with CID may improve surgical and performance outcomes, particularly regarding parameters of overall clinical improvement, length of stay, and postoperative complications.

Narenthiran et al have published their experience in 19 patients using intraoperative ultrasound to assess intraoperatively the indication for duraplasty. ${ }^{36}$ They did not open the dura if there was adequate cerebellar tonsillar and/or CSF pulsation following suboccipital craniectomy. Eight patients underwent dural decompression and 11 patients had bony decompression only. Clinical outcomes and complication rates were very similar between these groups. In line with this, the role of intraoperative neurophysiological monitoring (IOM) in the surgical treatment of CID has been also described; however, its clinical implications are yet to be defined. ${ }^{37}$

6) What are the best treatment options when CID patients also have syringomyelia?

Some controversy remains whether syringomyelia in patients with CID is a strict surgical indication, since the medical literature has several descriptions of spontaneous resolution of the syrinx in such cases or at least stability/ absence of progression, even in cases of large syringomyelic cavities. ${ }^{38,39}$ Magge et al studied 48 children with an idiopathic syrinx and found out that $91 \%$ of them remained clinically asymptomatic, stable or improved over a mean follow-up of 23.8 months. ${ }^{40}$ In those who had follow-up imaging, 87.5\% remained radiologically stable or the syrinx reduced over time, with no apparent correlation between changes in size of the syrinx and evolution of symptoms.

Nevertheless, Wetjen et $\mathrm{al}^{41}$ recommended surgical treatment by means of FMD whenever syringomyelia is associated with CID in children. Their study revealed that resolution of syringomyelia could be achieved after FMD in $86 \%$ of the cases. In unfortunate cases where symptomatic syringomyelia does not resolve after FMD, shunting might be an alternative solution, with reported good results for both syringoarachnoid and syringopleural shunt techniques. ${ }^{42,43}$

7) When should patients with CID be reoperated?

Hidalgo et $\mathrm{al}^{44}$ reviewing their experience with 105 consecutive children who underwent surgical decompression of symptomatic CID with duraplasty, found that symptoms had resolved by the time of discharge from the hospital in the majority (57\%) of children, and syrinx had resolved or decreased in two-thirds of the patients by 3 months of follow-up. By 6 months, headaches had resolved in all cases, and syrinx had resolved or decreased in $79 \%$ of the cases.

In the cases where symptoms did not subside, indications for reoperation included persistence of syringomyelia, ${ }^{20-22}$ 
persistent cranial nerves palsies ${ }^{24,25}$ and other neurological symptoms. Children $<3$ years old appear to have worse outcomes. ${ }^{25}$ Furthermore, Goel et $\mathrm{al}^{45}$ have published their experience with atlantoaxial fixation for Chiari 1 deformity in the pediatric age group (33 cases), reporting gratifying and sustained clinical improvement in all patients.

The conclusion of the consensus taskforce is that reoperation should be considered particularly in cases of persistent symptoms and/or of neurological deficits, especially when no CSF flow or a compressed brainstem are still visible on postoperative scans. Failure of syringomyelia remission, along with clinical features, is another strong indicator for reoperation. Nonetheless, another agreement of the taskforce important to highlight is that, if clinical improvement has been achieved, a persistent syringomyelia can be closely followedup. Volumetric reduction of the tonsils is another possibility if the bony and dural decompression are deemed satisfactory. The further need for fixation is addressed below.

8) Is there any evidence to support sectioning of the filum terminale as a first line therapy for CID?

To the best of our knowledge, only two peer-reviewed clinical studies have dealt with this topic so far. Royo-Salvador et $\mathrm{al}^{46}$ published in 2005 the results of 20 patients with CID treated through section of the filum terminale, reporting clinical improvement in all cases. A second study, published by Milhorat et $\mathrm{al}^{47}$ in 2009, examined 318 individuals with spinal cord and tonsillar herniation who underwent section of the filum, compared with matched controls and subjects with Chiari without spinal cord tethering, showing clinical and/or radiological improvement in $85 \%$ of them. However, it should be emphasized that these were patients with the diagnosis of tethered spinal cord, who would have usually undergone section of the filum as first-line treatment anyway. Therefore, the heterogeneity of the studied subjects with presentation of mixed pathologies precludes reliable statistical analysis and further recommendations based on these results.

From an experimental standpoint, a project conducted by Tubbs et $\mathrm{al}^{48}$ studied 12 adult cadavers submitted to the application of distal tension ( $75 \mathrm{~N}$ ) to the spinal cord, with simultaneous observation of the cervical spinal cord, the brainstem and the rhombencephalon and their relation to the foramen magnum after occipital craniectomy and removal of the posterior arch of $\mathrm{C} 1$. These authors did not observe any movement of the cerebellar tonsils and only 2 to $3 \mathrm{~mm}$ caudal descent of the brainstem and cervical spinal cord, concluding that, in the cadaveric model, caudal fixation of the distal spinal cord is unlikely to result in inferior displacement of the cerebellar tonsils, and therefore, transection of the filum terminale is likewise unlikely to reverse tonsillar ectopia.

Lastly, Massimi et $\mathrm{al}^{49}$ stated that there is still no convincing evidence on the association between CID and tethered spinal cord. Nevertheless, the authors concluded that section of the filum terminale may play a role in a small selected subgroup of patients with CID with poorly symptomatic tonsillar herniation, normal posterior fossa volume and evident symptoms of a tethered spinal cord.

As demonstrated, the consensus taskforce has performed a thorough and insightful analysis of the medical literature on the subject and found that there is no strong scientific evidence to support this therapeutic option, which remains, to our knowledge, experimental and with no scientific background. Therefore, the taskforce understands that only exceptional cases can benefit from this strategy and, thus, there is no generally accepted surgical indication of section of the filum terminale for the treatment of CID in children.

9) When should CID patients undergo craniocervical fusion and instrumentation? What are the current recommended approaches? How many levels should be included?

The work of Goel ${ }^{50-52}$ has introduced a new paradigm for treating CID; the author has recently suggested that C1-2 fixations should be performed for all cases, considering that tonsillar herniation is secondary (and a protective and compensatory mechanism) to the subtle or gross instability that seems to be present in cases of CID. Although the outcome has been reported as positive, this method of treatment has not been generally accepted yet as a standard mode of treatment for CID. ${ }^{53}$

Brockmeyer et al reviewed the medical literature in 2011 and concluded that C1-C2 fixation is indicated in complex CID patients with basilar invagination (BI) associated with $\mathrm{C} 1-\mathrm{C} 2$ instability. ${ }^{54,55}$ It also depends on the type of BI: type I requires instrumentation and fusion plus traction; in BI type II, fixation is recommended for selected cases, and some cases are to be decompressed only. Posterior C1-C2 fusion is also recommended in cases in which wide bone resections are necessary and should include as few levels as possible. ${ }^{56,57}$

Menezes, in 2012, analyzed his large series ( $>850$ procedures) of posterior instrumentation for CID children and reported a $98 \%$ rate of successful fusion. ${ }^{58}$ The author recommended that rigid fixation with screws and rods could be performed in patients older $>6$ years old, and in younger children rib grafts should be harvested. Similar results were reported by Mackel et $\mathrm{al}^{59}$ and Kim et al. ${ }^{60}$ Kennedy et al have also demonstrated that most young children undergoing atlatoaxial and occipitocervical fusion with rigid internal fixation continue to have good cervical alignment and continued growth within the fused levels during a prolonged follow-up period. ${ }^{61}$

10) Is there any evidence to support a genetic component in the genesis of CID?

Only a few studies have addressed this issue, ${ }^{62-66}$ with most data coming from familiar clusters of CID and syringomyelia patients. ${ }^{60,61}$ Nevertheless, a genetic component has been shown particularly in CID cases associated with connective tissue diseases ${ }^{64}$ and in some cases had mutations in the WNT pathways. ${ }^{65}$ Also, a positive familial history is present in $12 \%$ of patients with newly-diagnosed CID. ${ }^{64}$ Urbizu et al have found single nucleotide polymorphisms in 14 genes (CDX1, FLT1, RARG, NKD2, MSGN1, RBPJ1, FGFR1, RDH10, NOG, RARA, LFNG, KDR, ALDH1A2, and BMPR1A), suggesting that common variants in genes involved in somatogenesis and fetal vascular development may confer susceptibility to CID. ${ }^{66}$

\section{Acknowledgments}

The authors, and the Brazilian Society of Pediatric Neurosurgery, would like to acknowledge and thank all 
members of the consensus taskforce on Chiari I who made possible the production of these guidelines: Vinicius de Meldau Benites (São Paulo, SP), Fabio Takeda (Londrina, PR), Carlos Eduardo Barros Jucá (Fortaleza, CE), Rilton Moraes (Aracaju, SE), Jorge Bizzi (Porto Alegre, RS), José Francisco Manganelli Salomão (Rio de Janeiro, RJ), Vinicius Marques Carneiro (Ribeirão Preto, SP), Ricardo de Amoreira Gepp (Brasília, DF), Roger Brock (São Paulo, SP), Paulo Ronaldo Jubé Ribeiro (Goiânia, GO), Christian Diniz (João Pessoa, PB), Cármine Porcelli Salvarani (Maringá, PR), Angelo Raimundo da Silva Neto (Natal, RN), Charles Kondagesky (Florianópolis, SC), Tatiana Protzenko Cervante (Rio de Janeiro, RJ), Benedicto Oscar Colli (Ribeirão Preto, SP), Hamilton Matushita (São Paulo, SP), and Marcio Ferreira Marcelino (Brasília, DF).

\section{References}

1 Entezami P, Gooch MR, Poggi J, Perloff E, Dupin M, Adamo MA. Current management of pediatric chiari type 1 malformations. Clin Neurol Neurosurg 2019;176:122-126

2 Oxford Center for Evidence Based Medicine. [June 6, 2012]. http:// www.cebm.net $/$ index.aspx?o=5653

3 Collange NZ, Brito SdeA, Campos RR, Santos EAS, Botelho RV; Sociedade Brasileira de Neurocirurgia. Treatment of medulloblastoma in children and adolescents. Rev Assoc Med Bras (1992) 2016;62(04):298-302

4 Canheu AC, Santos MV, Furlanetti LL, Salomão JFM, de Oliveira RS. The Brazilian Society for Pediatric Neurosurgery: consensus on Chiari I deformity. Childs Nerv Syst 2019

5 Thompson DNP. Chiari I - a 'not so' congenital malformation? Childs Nerv Syst 2019

6 Chiari H. Über Veränderungen des Kleinhirns infolge von Hydrocephalie des Grosshirns. Dtsch Med Wochenschr 1891;17:1172-1175

7 Menezes AH. Craniocervical developmental anatomy and its implications. Childs Nerv Syst 2008;24(10):1109-1122

8 Bordes S, Jenkins S, Tubbs RS. Defining, diagnosing, clarifying, and classifying the Chiari I malformations. Childs Nerv Syst 2019;35 (10):1785-1792

9 Langridge B, Phillips E, Choi D. Chiari Malformation Type 1: A Systematic Review of Natural History and Conservative Management. World Neurosurg 2017;104:213-219

10 Khalsa SSS, Geh N, Martin BA, et al. Morphometric and volumetric comparison of 102 children with symptomatic and asymptomatic Chiari malformation Type I. J Neurosurg Pediatr 2018;21(01):65-71

11 Nishikawa M, Sakamoto H, Hakuba A, Nakanishi N, Inoue Y. Pathogenesis of Chiari malformation: a morphometric study of the posterior cranial fossa. J Neurosurg 1997;86(01):40-47

12 Basaran R, Efendioglu M, Senol M, Ozdogan S, Isik N. Morphometric analysis of posterior fossa and craniovertebral junction in subtypes of Chiari malformation. Clin Neurol Neurosurg 2018;169:1-11

13 Rijken BF, Lequin MH, van der Lijn F, et al. The role of the posterior fossa in developing Chiari I malformation in children with craniosynostosis syndromes. J Craniomaxillofac Surg 2015;43(06): 813-819

14 Milhorat TH, Nishikawa M, Kula RW, Dlugacz YD. Mechanisms of cerebellar tonsil herniation in patients with Chiari malformations as guide to clinical management. Acta Neurochir (Wien) 2010;152 (07):1117-1127

15 Poretti A, Ashmawy R, Garzon-Muvdi T, Jallo GI, Huisman TA, Raybaud C. Chiari Type 1 Deformity in Children: Pathogenetic, Clinical, Neuroimaging, and Management Aspects. Neuropediatrics 2016;47(05):293-307

16 Novegno F, Caldarelli M, Massa A, et al. The natural history of the Chiari Type I anomaly. J Neurosurg Pediatr 2008;2(03):179-187
17 Strahle J, Muraszko KM, Kapurch J, Bapuraj JR, Garton HJ, Maher CO. Natural history of Chiari malformation Type I following decision for conservative treatment. J Neurosurg Pediatr 2011;8 (02):214-221

18 Volpon Santos M, Rodrigues D, Solanki G. Clinical \& radiological progression of paediatric Chiari I malformation: 10-year outpatient follow-up review. Childs Nerv Syst 2012;28:755-806

19 Pomeraniec IJ, Ksendzovsky A, Awad AJ, Fezeu F, Jane JA Jr. Natural and surgical history of Chiari malformation Type I in the pediatric population. J Neurosurg Pediatr 2016;17(03):343-352

20 Vinchon M. Surgery for Chiari 1 malformation: the Lille experience. Childs Nerv Syst 2019;35(10):1875-1880

21 Low SYY, Ng LP, Tan AJL, Low DCY, Seow WT. The Seow Operative Score (SOS) as a decision-making adjunct for paediatric Chiari I malformation: a preliminary study. Childs Nerv Syst 2019;35(10): 1777-1783

22 Klekamp J. Surgical treatment of Chiari I malformation-analysis of intraoperative findings, complications, and outcome for 371 foramen magnum decompressions. Neurosurgery 2012;71(02): 365-380, discussion 380

23 Volpon Santos M, Machado HR. Malformação de Chiari I em crianças. In: Tratado de Neurocirurgia - Sociedade Brasileira de Neurocirurgia, 1 ${ }^{\text {a }}$ Ed. São Paulo: Manole Editora; 2015

24 Aitken LA, Lindan CE, Sidney S, et al. Chiari type I malformation in a pediatric population. Pediatr Neurol 2009;40(06):449-454

25 Jarski P, Zimny M, Linart M, Kozłowska Z, Mandera M. Results of the surgical treatment in children with Chiari malformation type I. Childs Nerv Syst 2019;35(10):1911-1914

26 Barkovich AJ, Wippold FJ, Sherman JL, Citrin CM. Significance of cerebellar tonsillar position on MR. AJNR Am J Neuroradiol 1986; 7(05):795-799

27 Milhorat TH, Chou MW, Trinidad EM, et al. Chiari I malformation redefined: clinical and radiographic findings for 364 symptomatic patients. Neurosurgery 1999;44(05):1005-1017

28 Caldarelli M, Novegno F, Vassimi L, Romani R, Tamburrini G, Di Rocco $C$. The role of limited posterior fossa craniectomy in the surgical treatment of Chiari malformation Type I: experience with a pediatric series. J Neurosurg 2007;106(3, Suppl)187-195

29 Cinalli G, Spennato P, Sainte-Rose C, et al. Chiari malformation in craniosynostosis. Childs Nerv Syst 2005;21(10):889-901

30 Addo NK, Javadpour S, Kandasamy J, Sillifant P, May P, Sinha A. Central sleep apnea and associated Chiari malformation in children with syndromic craniosynostosis: treatment and outcome data from a supraregional national craniofacial center. J Neurosurg Pediatr 2013;11(03):296-301

31 Ahmad F, Evans M, White N, et al. Amelioration of Chiari type 1 malformation and syringomyelia following posterior calvarial distraction in Crouzon's syndrome-a case report. Childs Nerv Syst 2014;30(01):177-179

32 Durham SR, Fjeld-Olenec K. Comparison of posterior fossa decompression with and without duraplasty for the surgical treatment of Chiari malformation Type I in pediatric patients: a metaanalysis. J Neurosurg Pediatr 2008;2(01):42-49

33 Hankinson T, Tubbs RS, Wellons JC. Duraplasty or not? An evidence-based review of the pediatric Chiari I malformation. Childs Nerv Syst 2011;27(01):35-40

34 Lin W, Duan G, Xie J, Shao J, Wang Z, Jiao B. Comparison of Results Between Posterior Fossa Decompression with and without Duraplasty for the Surgical Treatment of Chiari Malformation Type I: A Systematic Review and Meta-Analysis. World Neurosurg 2018; 110:460-474.e5

35 Lu VM, Phan K, Crowley SP, Daniels DJ. The addition of duraplasty to posterior fossa decompression in the surgical treatment of pediatric Chiari malformation Type I: a systematic review and meta-analysis of surgical and performance outcomes. J Neurosurg Pediatr 2017;20(05):439-449

36 Narenthiran G, Parks C, Pettorini B. Management of Chiari I malformation in children: effectiveness of intra-operative 
ultrasound for tailoring foramen magnum decompression. Childs Nerv Syst 2015;31(08):1371-1376

37 Barzilai O, Roth J, Korn A, Constantini S. The value of multimodality intraoperative neurophysiological monitoring in treating pediatric Chiari malformation type I. Acta Neurochir (Wien) 2016;158(02):335-340

38 Sun PP, Harrop J, Sutton LN, Younkin D. Complete spontaneous resolution of childhood Chiari I malformation and associated syringomyelia. Pediatrics 2001;107(01):182-184

39 Pindrik J, Johnston JM Jr. Clinical Presentation of Chiari I Malformation and Syringomyelia in Children. Neurosurg Clin N Am 2015;26(04):509-514

40 Magge SN, Smyth MD, Governale LS, et al. Idiopathic syrinx in the pediatric population: a combined center experience. J Neurosurg Pediatr 2011;7(01):30-36

41 Wetjen NM, Heiss JD, Oldfield EH. Time course of syringomyelia resolution following decompression of Chiari malformation Type I. J Neurosurg Pediatr 2008;1(02):118-123

42 Soleman J, Roth J, Bartoli A, Rosenthal D, Korn A, Constantini S. Syringo-Subarachnoid Shunt for the Treatment of Persistent Syringomyelia Following Decompression for Chiari Type I Malformation: Surgical Results. World Neurosurg 2017;108: 836-843

43 Fan T, Zhao X, Zhao H, et al. Treatment of selected syringomyelias with syringo-pleural shunt: the experience with a consecutive 26 cases. Clin Neurol Neurosurg 2015;137:50-56

44 Hidalgo ET, Dastagirzada Y, Orillac C, et al. Time to Resolution of Symptoms After Suboccipital Decompression with Duraplasty in Children with Chiari Malformation Type I. World Neurosurg 2018; 117:e544-e551

45 Goel A, Gore S, Shah A, Dharurkar P, Vutha R, Patil A. Atlantoaxial Fixation for Chiari 1 Formation in Pediatric Age-Group Patients: Report of Treatment in 33 Patients. World Neurosurg 2018;111: e668-e677

46 Royo-Salvador MB, Solé-Llenas J, Doménech JM, González-Adrio R. Results of the section of the filum terminale in 20 patients with syringomyelia, scoliosis and Chiari malformation. Acta Neurochir (Wien) 2005;147(05):515-523, discussion 523

47 Milhorat TH, Bolognese PA, Nishikawa M, et al. Association of Chiari malformation type I and tethered cord syndrome: preliminary results of sectioning filum terminale. Surg Neurol 2009;72(01):20-35

48 Tubbs RS, Loukas M, Shoja MM, Oakes WJ. Observations at the craniocervical junction with simultaneous caudal traction of the spinal cord. Childs Nerv Syst 2007;23(04):367-369

49 Massimi L, Peraio S, Peppucci E, Tamburrini G, Di Rocco C. Section of the filum terminale: is it worthwhile in Chiari type I malformation? Neurol Sci 2011;32(Suppl 3):S349-S351

50 Goel A. Is atlantoaxial instability the cause of Chiari malformation? Outcome analysis of 65 patients treated by atlantoaxial fixation. J Neurosurg Spine 2015;22(02):116-127
51 Goel A. Is Chiari malformation nature's protective "air-bag"? Is its presence diagnostic of atlantoaxial instability?. J Craniovertebr Junction Spine 2014;5(03):107-109

52 Goel A. A review of a new clinical entity of 'central atlanto- axial instability': expanding horizons of craniovertebral junction surgery. Neurospine 2019;16(02):186-194

53 Sarat Chandra P. Craniovertebral Junction Anomalies: Changing Paradigms, Shifting Perceptions: Where Are We and Where Are We Going? Neurospine 2019;16(02):209-211

54 Brockmeyer DL, Oakes WJ, Rozzelle C, et al. Chiari malformation Type 1 and atlantoaxial instability: a letter from the Pediatric Craniocervical Society. J Neurosurg Spine 2015;23(06):820-821

55 Brockmeyer DL. The complex Chiari: issues and management strategies. Neurol Sci 2011;32(Suppl 3):S345-S347

56 Goldstein HE, Anderson RC. Craniovertebral Junction Instability in the Setting of Chiari I Malformation. Neurosurg Clin N Am 2015; 26(04):561-569

57 Kelly MP, Guillaume TJ, Lenke LG. Spinal Deformity Associated with Chiari Malformation. Neurosurg Clin N Am 2015;26(04):579-585

58 Menezes AH. Craniocervical fusions in children. J Neurosurg Pediatr 2012;9(06):573-585

59 Mackel CE, Cahill PJ, Roguski M, et al. Factors associated with spinal fusion after posterior fossa decompression in pediatric patients with Chiari I malformation and scoliosis. J Neurosurg Pediatr 2016;25(06):737-743

60 Kim LJ, Rekate HL, Klopfenstein JD, Sonntag VK. Treatment of basilar invagination associated with Chiari I malformations in the pediatric population: cervical reduction and posterior occipitocervical fusion. J Neurosurg 2004;101(2, Suppl)189-195

61 Kennedy BC, D'Amico RS, Youngerman BE, et al; Pediatric Craniocervical Society. Long-term growth and alignment after occipitocervical and atlantoaxial fusion with rigid internal fixation in young children. J Neurosurg Pediatr 2016;17(01):94-102

62 Abbott D, Brockmeyer D, Neklason DW, Teerlink C, CannonAlbright LA. Population-based description of familial clustering of Chiari malformation Type I. J Neurosurg 2018;128(02): 460-465

63 Nagy L, Mobley J, Ray C. Familial Aggregation of Chiari Malformation: Presentation, Pedigree, and Review of the Literature. Turk Neurosurg 2016;26(02):315-320

64 Markunas CA, Lock E, Soldano K, et al. Identification of Chiari Type I Malformation subtypes using whole genome expression profiles and cranial base morphometrics. BMC Med Genomics 2014;7:39

65 Merello E, Tattini L, Magi A, et al. Exome sequencing of two Italian pedigrees with non-isolated Chiari malformation type I reveals candidate genes for cranio-facial development. Eur J Hum Genet 2017;25(08):952-959

66 Urbizu A, Toma C, Poca MA, et al. Chiari malformation type I: a case-control association study of 58 developmental genes. PLoS One 2013;8(02):e57241 